\title{
IDENTIFICATION OF GOOD PRACTICES FOR RAILWAY SYSTEMS IN URBAN AREAS
}

DATA PRZESŁANIA: 06.11.2018, DATA AKCEPTACJI: 14.01.2019, KODY JEL: R40

\section{Piotr Soczówka, Renata Żochowska, Aleksander Sobota, Marcin Jacek Kłos}

\author{
Politechnika Śląska \\ piotr.soczowka@polsl.pl \\ renata.zochowska@polsl.pl \\ aleksander.sobota@polsl.pl \\ marcin.j.klos@polsl.pl
}

\begin{abstract}
SUMMARY $\quad$ In many urban areas railway systems have been introduced in recent years. Rapid metropolitan railway may be solution to many transport problems of modern urban agglomerations such as congestion or pollution. In order to encourage people to use means of public transport such as metropolitan railway systems it is necessary to introduce solutions for its functioning which are beneficial. The paper presents a procedure of identifying such solutions - which are called good practices, in existing metropolitan railway systems. Identified solutions may be later transferred to other systems to increase the level of service.

KEYWORDS $\quad$ metropolitan railway system, good practices, urban agglomerations
\end{abstract}

\section{INTRODUCTION}

Railway systems in urban areas such as urban agglomerations or metropolitan areas have been becoming more and more important part of transport systems (Drewnowski, Małachowski, 2018). Urban areas are prone to congestion and parking problems and also suffer from pollution caused by transport. Railway systems may be the way to reduce these problems. Therefore in recent years in many Polish urban agglomerations and metropolitan areas new systems of rapid urban railway have been introduced (eg. Poznań, Łódź) or have been in concept or implementation phase (e.g. Szczecin, Metropolis GZM). In order to increase the number of travels made by passengers of railway it is necessary to introduce advantageous solutions for its functioning.

Different terms are used to define railway systems operating in urban areas. It is caused by differences among these systems as well as among areas where they exist. Term "metro" is commonly used for describing rapid railway system with high capacity and frequency of operation, however according to (Rozporządzenie, 2002) it has to be separated from other traffic. In Poland, on the 
other hand, "metro" is associated with mostly underground systems. For trains that provide service between city centres and suburban areas usually term 'commuter rail' is used. In German speaking countries term "S-Bahn" is used for railway systems operating on the surface. Moreover, there are fuzzy boundaries between terms 'urban agglomeration' or "metropolitan area" (Fang, Yu, 2017). Therefore, in Poland different names are used for rapid railway systems, such as: "szybka kolej miejska" (rapid urban railway), "kolej metropolitalna" (metropolitan railway), "kolej aglomeracyjna" (agglomeration railway). In order to avoid misunderstanding and to unify the nomenclature, in this paper term 'metropolitan railway system' is used to describe rapid railway that is in operation in both urban agglomerations and metropolitan areas.

Designing new systems or solutions is a complex process that requires various and detailed analyses. One of many fields that should be taken into consideration is an analysis of already functioning systems (Serrat, 2010). Comparison different solutions may lead to identification of procedures or methods that have proven to be better than other procedures or methods (Bretschneider, Marc-Aurele, Wu, 2004). Transport systems are not an exception from that general rule. Performing a detailed case study of similar solutions from systems that are already in operation is necessary for introducing new system of transport to a given area. Benefits of this approach include avoiding mistakes from other conceptions and also allowing to choose particular solutions that may lead to effective outcome.

However, it is important to remember that solutions or methods from a given transport system should not be simply transferred to a different system. Other aspects that may be critical when determining if a given solution will be effective in different area should be also taken into consideration. There are several barriers, i.e. environmental aspects (inability to use certain means of transport), sociological (travel behaviours) etc. Nevertheless, identifying solutions or methods which are effective in other areas may still be useful at the stage of designing similar transport systems.

Set of procedures that has proven to be effective in a given organization or area is commonly called "good practices" (Serrat, 2010). Sometimes a term "best practices" is used, with a similar meaning, i.e. procedures that allow to reach high level of efficiency and successful outcomes (NRC, 2010). Although a word "procedure" has been used also some methods, methodologies, solutions or techniques may be considered as good practices. It is important that they have to be proven, basing on research and evaluation in order to be considered as "good practices" (Serrat, 2010).

In addition to increase of efficiency, research and study focused on identifying good practices may result in several other benefits (Serrat, 2010):

- replacing unwanted and poor practices,

- reduction of costs,

- improvement of service.

Identification of good practices in metropolitan railway systems or commuter rail systems may lead to some additional benefits. There are associated with a unique role of railway in transport systems - especially in urban or metropolitan areas. Metropolitan transport system can be considered as a whole, therefore introducing good practices in railway may cause increase of efficiency in other parts of transport system. Also, when it comes to public transport in general, 
good practices may help to increase the level of passengers' satisfaction, what eventually may lead to growth of percentage share of travels made using public transport system.

\section{METHOD OF IDENTIFICATION OF GOOD PRACTICES FOR METROPOLITAN RAILWAY SYSTEMS}

In order to propose a method of identification of good practices for metropolitan railway system an assumption has been made that a source of such practices should be already functioning systems which achieve excellent or very good results in comparison to other systems in a given country. It is assumed that such systems use solutions, procedures or methods which lead to high standard of service. A general procedure of identifying good practices in metropolitan railway systems has been presented in Fig. 1 .

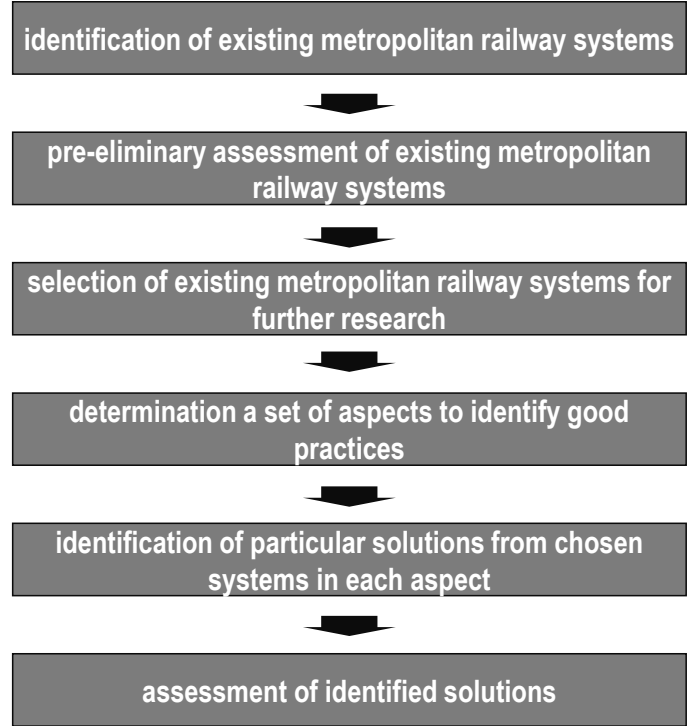

Figure 1. Procedure of identification of good practices in metropolitan railway systems

Source: own research.

First step of proposed method is the identification of all existing metropolitan railway systems in a country of analysis. Firstly, systems from the same country should be taken into account because objective analysis of metropolitan railway systems from different countries may be limited by non-technical aspects, such as law regulations or habits of passengers. However, it is possible to extend the range of analysis if needed.

Next step requires determination of set of criteria to preliminary assess each identified system. Such pre-elimination is conducted according to main assumption of the method - that good practices should be sought in systems that stand out from other existing systems. Pre-elimination allows to choose these metropolitan railway systems that fulfil that assumption. It is essential to choose criteria that allow to compare systems in a comprehensive and general way. There is no 
need to search for particular solutions at this stage of analysis. Examples of such criteria include but are not limited to:

- the number of passengers in a years of analysis, divided by the number of inhabitants in the area of service:

$$
C_{1}=\frac{\text { number of passengers in a year of analysis }}{\text { number of inhabitants in the area of service }}[-]
$$

- transport performance index, measured in [passengers ${ }^{\star}$ kilometres], divided by the number of inhabitants in the area of service:

$$
C_{2}=\frac{\text { value of transport performance index in a year of analysis }}{\text { number of inhabitants in the area of service }}[\mathrm{pas} * \mathrm{~km}]
$$

Thereafter, each metropolitan railway system is assessed basing on chosen criteria and that leads to determination of set of systems for further research. It is assumed that systems with best results at this stage should be chosen as these with potentially best practices.

In the next step a set of aspects of operation of metropolitan railway system to identify good practices should be determined. It means that good practices are not identified in general way but in particular areas of operation. Authors proposed five aspects of operation to identify good practices:

- infrastructure,

- rolling stock,

- organisation,

- functioning,

- integration.

In each of chosen aspect of operation particular solutions that are already implemented should be identified - they are potentially beneficial and may be treated as good practices.

Presented steps should lead to determination of set of particular solutions that give good results in already existing metropolitan railway systems in five different areas of operation. However, it is important to remember that before applying chosen solutions it is necessary to verify if they can be implemented in unchanged way. Therefore identified solutions should be assessed by researchers. There is no specific set of criteria at this stage. Solutions should be compared with researchers' goals, demands and preferences. If a chosen solution is taken from much bigger systems then financial aspects should be taken into consideration. There may also be law or environmental regulations as well as technical or sociological constraints.

\section{ASPECTS OF OPERATION OF METROPOLITAN RAILWAY SYSTEM}

In previous chapter authors suggested using five aspects of operation of metropolitan railway system to identify good practices. For each aspects particular solutions should be sought. 


\section{INFRASTRUCTURE}

Possible aspects of analysis of infrastructure has been presented in Fig. 2.

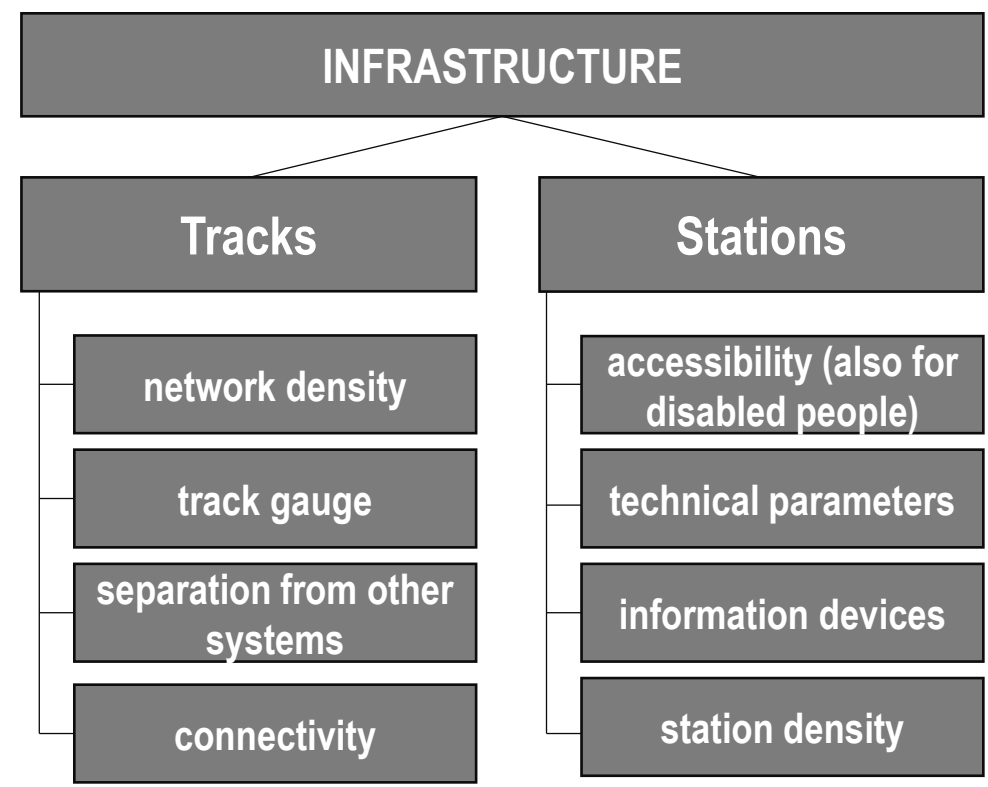

Figure. 2 Aspects of analysis of infrastructure

Source: own research.

There are two aspects that should be taken into consideration when analysing infrastructure of metropolitan railway system - tracks and stations. When analysing tracks, features such as track gauge or the level of separation from other systems should be considered. Separation from other systems may be understood both as separation from road transport or pedestrians and as separation from inter-city or regional trains. Network density and connectivity also may be taken into consideration.

When analysing stations it is important to consider accessibility (also spatial), especially for disabled people (lifts, ramps, etc.). Also technical parameters such as length or height of platforms must be taken into account. Not only is it necessary to identify specific values but also whether they are unified for the whole system. One should also analyse how information for passengers is provided on stations. Similarly to network density, station density may be also part of analysis. 


\section{ROLLING STOCK}

Possible aspects of analysis of rolling stock has been presented in Fig. 3.

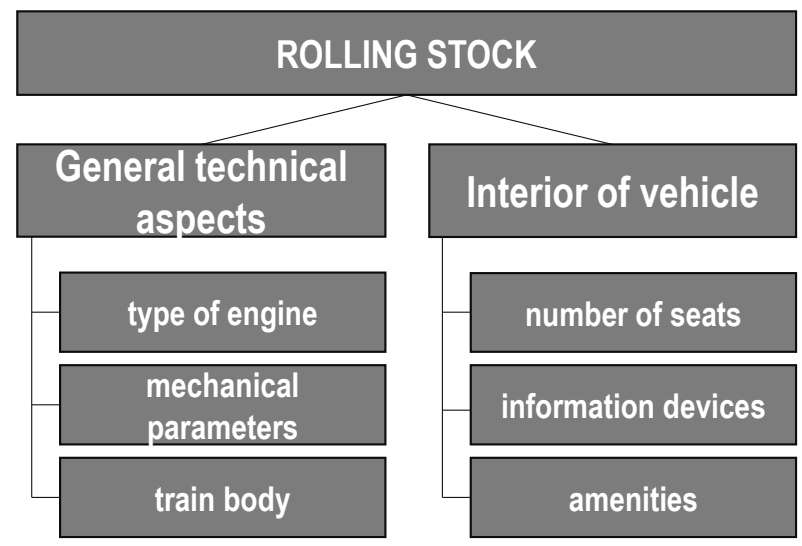

Figure 3. Aspects of analysis of rolling stock

Source: own research.

When analysing solutions for rolling stock, technical aspects such as type of engine (electrical only, diesel engine, hybrid engine) or mechanical parameters (i.e. acceleration) and parameters of train body should be considered. Parameters associated with train body may include length of vehicles, number of doors on each side of train or width of doors. Next area that should be taken into consideration is the interior of vehicle. That should include number of seats (also for disabled people or number of places for bicycles) or information devices. Last group of solutions to identify are the amenities for passengers, such as: air conditioning, displays, USB ports, electrical outlets, surveillance, etc.

\section{ORGANISATION}

Possible aspect of analysis of organisation of metropolitan railway system has been presented in Fig. 4.

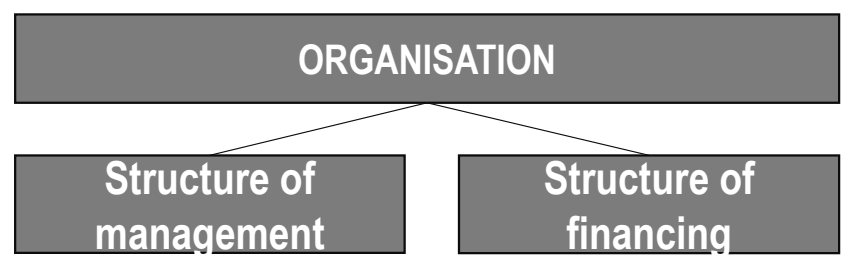

Figure 4. Aspect of analysis of organisation

Source: own research. 
Structure of management is the first aspect to consider when analysing organisation. It is important to establish who is the owner of the infrastructure, the rolling stock and who is in charge of organising the service of metropolitan railway systems. Second aspect is financing of the service.

\section{FUNCTIONING}

Possible aspects of analysis of functioning of metropolitan railway system has been presented in Fig. 5.

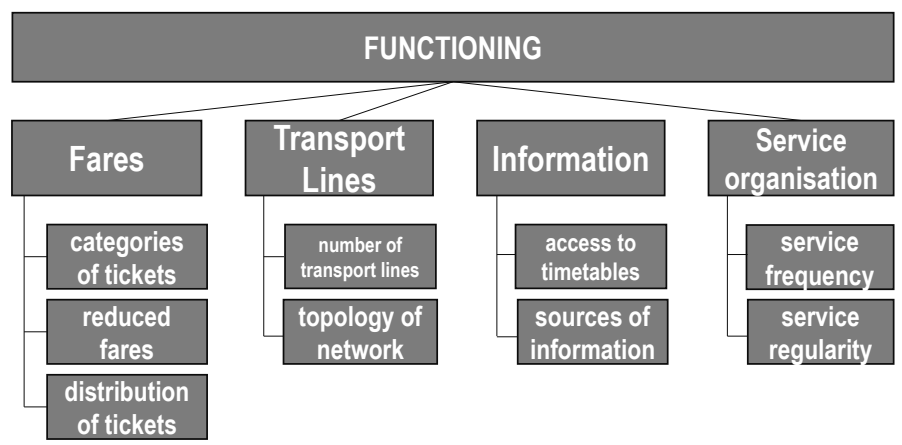

Figure 5 Aspects of analysis of functioning

Source: own research.

There are four general groups of aspects of functioning that should be analysed. First of them is associated with fares. That includes categories of tickets, fares and also reduced-fares (including determination who is eligible for reduced-fares and on what conditions). An important aspect are solutions for distribution of tickets - such as tickets machines or mobile app.

Other aspect are transport lines - it is important to consider the number of lines and also topology of the network.

Third aspect of functioning is associated with information. That includes sources of information for passengers (websites, smartphone apps, etc.). There may be different ways to provide access to timetables, except via Internet, such as timetables on stations or inside vehicles.

Last aspect is the organisation of service: frequency and regularity of service should be considered, including service in traffic peak and at night.

It is important to remember that particular solutions of functioning may be strongly connected with other aspects such as infrastructural constraints or the structure of management. Therefore it is essential to always analyse all five aspects as there may be connections which should be identified. 


\section{INTEGRATION}

Possible aspects of analysis of integration has been presented in fig. 6 .

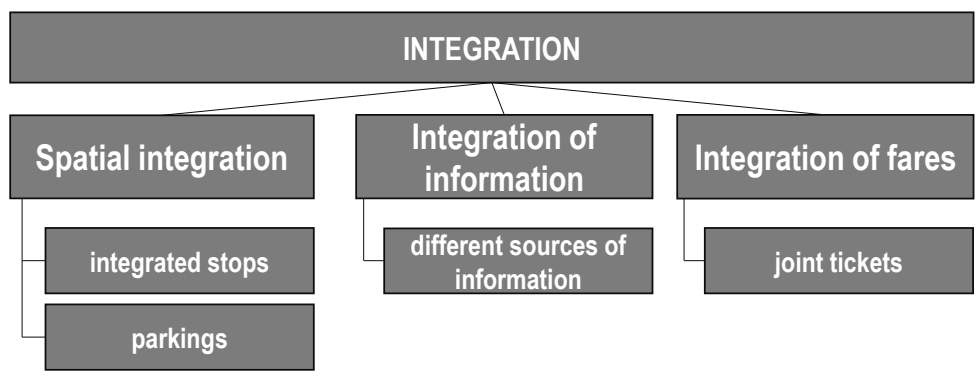

Figure 6 Aspects of analysis of integration

Source: own research.

There are three groups of aspects of integration to consider - first is the spatial integration what includes solutions of easy transfer between trains of metropolitan railway system and other means of public transport (buses, trams etc.) i.e. on integrated stops. Also parking (i.e. P\&R) for public transport users might be analysed.

Second aspect is the integration of information and methods of providing information for passengers. If metropolitan railway systems and other systems of public transport are organised by different entities it is important to provide information about joint tickets or timetables on websites.

Last aspect is the integration of fares for different systems of public transport - it is necessary to identify whether there are any joint tickets and on what condition passengers may transfer between different means of transport.

\section{CASE STUDY OF POLISH METROPOLITAN RAILWAY SYSTEMS}

Five of existing Polish metropolitan railway systems have been chosen to present the procedure of identifying good practices. For the stage of pre-elimination following systems have been selected:

- PKP SKM Trójmiasto,

- SKM Warszawa (SKM Warsaw),

- ŁKA (Łódzka Kolej Aglomeracyjna),

- SKA (Szybka Kolej Aglomeracyjna),

- PKM (Poznańska Kolej Metropolitalna).

First of these systems - PKP SKM Trójmiasto operates in the region of Gdańsk Bay and connects Gdańsk, Sopot and Gdynia with smaller towns in that region, like Wejherowo or Kościerzyna. The system currently consists of six transport lines.

SKM Warszawa (Warsaw) is the metropolitan railway system that is in operation in the capital city of Poland. It has been operating since 2004 and there are currently five transport lines. The system connects centre of Warsaw with a few important locations like the airport or the National Stadium. 
ŁKA (Łódzka Kolej Aglomeracyjna) is the system operating in central Poland - in and around the city of Łódź. There are five transport lines connecting Łódź with Łowicz, Kutno, Zgierz or Sieradz. There is also one longer line that connects Łódź and Warsaw.

SKA (Szybka Kolej Aglomeracyjna) is a system that is in operation mostly in the region around city of Kraków (Cracow) in Małopolska. There are three lines, connecting Kraków with i.e. Tarnów, Wieliczka or Miechów.

PKM (Poznańska Kolej Metropolitalna) is a rather new systems (it has been in operation since 2018) in Wielkopolska region. Currently there are three lines that connect Poznan with other cities in Wielkopolska: Nowy Tomyśl, Jarocin or Swarzędz.

According to proposed procedure the first step to identify good practices is the pre-elimination. That allows to choose for further analysis these systems that produce very good results in comparison to other systems. Systems have been assessed basing on the criterion $\mathrm{C}_{1}$ (total number of passengers in 2017, divided by total number of inhabitants in the area of service). Following assumptions have been made:

1. Poznańska Kolej Metropolitalna has been eliminated from the analysis before calculations due to short time since its inauguration. Systems chosen for analysis should be comparable with other systems (Bretschneider, Marc-Aurele, Wu, 2004) and a few months of service is insufficient.

2. According to the timetable, service for Szybka Kolej Aglomeracyjna is provided by Koleje Małopolskie. However, this carrier has also transport lines which are not labelled as SKA. Therefore, total number of passengers for Koleje Małopolskie has been proportionally reduced, basing on the total number of trips and those labelled as SKA.

Basing on the data from UTK (Railway Transport Office) and BDL (Bank of Local Data) following calculations have been conducted:

Table 1. Comparison of analysed systems

\begin{tabular}{|l|c|c|c|}
\hline \multicolumn{1}{|c|}{ System } & $\begin{array}{c}\text { Number of inhabitants } \\
\text { in the area of service }[\mathrm{mln}]\end{array}$ & $\begin{array}{c}\text { Number of passengers } \\
\text { in } 2017[\mathrm{mln}]\end{array}$ & ${\text { Criterion } \mathrm{C}_{1}[-]}$ \\
\hline PKP SKM Trójmiasto & ca. 0,97 & ca. 39,47 & 40,7 \\
\hline SKM Warszawa & ca. 2,00 & ca. 23,07 & 11,6 \\
\hline ŁKA & ca. 1,10 & ca. 3,85 & 3,5 \\
\hline SKA & ca. 1,00 & ca. 5,17 & 5,17 \\
\hline
\end{tabular}

Source: own research based on data from http://utk.gov.pl and http://bdl.stat.gov.pl.

Basing on table 1 two systems of metropolitan railway have been selected for further analysis: PKP SKM Trójmiasto and SKM Warszawa (SKM Warsaw).

\section{EXAMPLES OF SOLUTIONS IN SELECTED METROPOLITAN RAILWAY SYSTEMS}

Particular solutions from two selected metropolitan railway systems have been presented. Five aspects of operation have been taken into consideration. It is important to remember that no specific criteria have been established at this stage. Each identified solution may be potentially chosen as 
good practice but before deciding if could be transferred to a different system it is necessary to take other aspects into account, i.e. economics, environment, geology, demographics, existing traffic, etc.

\section{INFRASTRUCTURE}

An example of potentially beneficial solutions is a total separation from other traffic on railway line 250 which connects Gdańsk, Sopot and Gdynia with Rumia. It is managed and operated by PKP SKM Trójmiasto. Separation from other traffic may be crucial when providing demanded level of frequency of service.

Both systems use standard track gauge: 1435 [mm].

There are speakers and displays to provide information for passengers on stations in both systems. Devices such as lifts or ramps are also used in order to make stations more accessible for disabled people.

\section{ROLLING STOCK}

SKM Warszawa (SKM Warsaw) uses only electric multiple units. Most of vehicles owned by PKP SKM Trójmiasto also electric multiple units.

Vehicles in Warsaw are equipped with ticket machines and also USB ports (selected vehicles), air-conditioning, displays, speakers, surveillance cameras. There is rather wide range of length of vehicles in both systems, which may allow flexibility when assigning trains to different transport lines.

\section{ORGANISATION}

PKP (Polish National Railways) has the most shares of the system. Other stakeholders include Pomeranian Voivodship and local authorities. SKM Warszawa (SKM Warsaw) is managed by Warsaw Transport Authority and the city of Warsaw is the stakeholder.

\section{FUNCTIONING}

PKP SKM Trójmiasto provide a high level of frequency on the most important part of its network between Gdynia and Gdańsk. Trains leave each station on average every ten minutes.

SKM Warszawa (SKM Warsaw) uses two categories of reduced fares: $100 \%$ reduction or 50\% reduction. It may turn out to be easier for passengers than a few categories of tickets in PKP SKM Trójmiasto.

Both systems provide information about timetables, fares and general information about system on their websites. SKM Warszawa (SKM Warsaw) provides information about delays by a smartphone app. Both systems offer a variety of ways to purchase tickets: using Internet, ticket machines or ticket offices.

\section{INTEGRATION}

SKM Warszawa (SKM Warsaw) is fully integrated with other public transport systems in Warsaw. Passengers may travel by bus, tram or SKM train using the same ticket. Also all information about SKM is provided on the website of Warsaw Transport Authority. 
There are park and ride lots located in Warsaw which are dedicated for public transport users.

In both systems stations are located in close vicinity of bus/trams stops in order to provide possibility of interchange between systems.

\section{CONCLUSIONS}

Metropolitan railway systems have become a very significant part of transport system in urban areas. Properly functioning systems of metropolitan railway may be a solution to congestion or pollution problems in such areas. In order to encourage inhabitants and visitors to use railway systems it is necessary to implement solutions which turned out to be user friendly and provide satisfactory outcomes. It is especially important at the stage of designing new system but it is necessary to introduce good practices to already functioning systems to maintain high level of service.

A procedure of identification of good practices for metropolitan railway systems with its main assumptions has been presented in the article. Each proposed aspect of analysis of existing metropolitan railway systems has been described. Chosen Polish metropolitan railway systems have been selected for a case study and identification of particular solutions.

Identification of good practices in metropolitan railway systems may lead to higher level of service and as a result more people may be encouraged to choose public transport over a car or other means of individual transport. It may be a first step to solve transport problems in urban areas all over the world.

\section{REFERENCES}

Bretschneider, S., Marc-Aurele, F., Wu, J. (2004). "Best Practices” Research: A Methodological Guide for the Perplexed. Journal of Public Administration Research and Theory, 15 (2), 307-323.

Drewnowski, A., Małachowski, K. (2018). Problematyka efektywnej realizacji przewozów pasażerskich w głównych relacjach w ramach koncepcji Szczecińskiej Kolei Metropolitalnej. Problemy Transportu i Logistyki, 41 (1), $29-41$.

Fang, C., Yu, D. (2017). Urban agglomeration: An evolving concept of an emerging phenomenon. Landscape and Urban Planning, 162, 126-136.

Serrat, O. (2010). Knowledge Solutions. Tools, methods, and approaches to drive development forward and enhance its effects. Manila: Asian Development Bank.

Rozporządzenie (WE) nr 91/2003 Parlamentu Europejskiego i Rady z dnia 16 grudnia 2002 r. w sprawie statystyki transportu kolejowego.

\section{Internet sources}

NRC (2010). Identifying and Promoting Effective Practices. Downloaded from: http://strengtheningnonprofits.org/ http://skm.pkp.pl

http://ztm.waw.pl

http://skm.warszawa.pl

http://lka.lodzkie.pl

http://kolej.metropoliapoznan.pl

http://malopolskiekoleje.pl

http://bdl.stat.gov.pl

http://utk.gov.pl 


\section{IDENTYFIKACJA DOBRYCH PRAKTYK W SYSTEMACH KOLEI W OBSZARACH MIEJSKICH}

STRESZCZENIE

SKOWA KLUCZOWE
W ostatnich latach uruchomiono wiele systemów kolei miejskich. Szybka kolej miejska może być sposobem na rozwiązanie problemów występujących w dużych aglomeracjach, takich jak kongestia czy zanieczyszczenie powietrza powodowane działalnością transportową. Aby zachęcić użytkowników systemu transportowego do korzystania ze środków publicznego transportu zbiorowego, w tym kolei, konieczne jest wprowadzanie rozwiązań korzystnych dla jego funkcjonowania. W artykule zaprezentowano procedurę identyfikacji takich rozwiązań - dobrych praktyk - w istniejących systemach kolei w obszarach miejskich. Zidentyfikowane rozwiązania mogą być następnie wprowadzone w innych ośrodkach miejskich $\mathrm{w}$ celu podniesienia poziomu obsługi.

systemy kolei metropolitalnej, dobre praktyki, aglomeracje miejskie 